Ethiopian Journal of Environmental Studies \& Management 7(1): 82 - 89, 2014

ISSN:1998-0507

doi: http://dx.doi.org/10.4314/ejesm.v7i1.10

Submitted: November 11, 2013

Accepted: February 3, 2014

\title{
INVESTIGATING THE EFFECTS OF SEWAGE ON THE GROUNDWATER QUALITY IN MINNA, NIGER STATE, NIGERIA
}

\author{
*ADESIJI, A.R., ${ }^{*}$ ADEOYE, P.A. ${ }^{2}$ AND GBADEBO, A.0. ${ }^{3}$ \\ ${ }^{1}$ Department of Civil Engineering, \\ University Putra, Malaysia, Darul Ehsan, Selangor. \\ ${ }^{2}$ Department of Biological and Agricultural Engineering, \\ University Putra, Malaysia, Darul Ehsan, Selangor. \\ ${ }^{3}$ Department of Hydraulics and River Basin Development, \\ Institute for Water Education, UNESCO-IHE., Delft, Netherlands.
}

\begin{abstract}
This study considers the effects of sewage on groundwater quality using Bosso area of Minna as a case study. Water samples were collected from three wells (boreholes) in three different locations within the study area in two different seasons (dry and wet) and were analyzed for physicochemical and bacteriological qualities. A multipurpose parameter was used for physicochemical analysis while for bacteriological the standard plate count method and the spread plate method were used. For physico-chemical analysis, the results show that well 3 has the highest values of the parameters observed: Total dissolved solids have the highest value of $540.02 \mathrm{mg} / \mathrm{L}$ during the dry season, nitrates and nitrites, $38.03 \mathrm{mg} / \mathrm{L}$ and $0.96 \mathrm{mg} / \mathrm{L}$ respectively during the wet season with standard deviations of 2.47 and 0.05 respectively. The highest values of chloride in well 3 during the wet season was $143.93 \mathrm{mg} / \mathrm{L}$ with standard deviation of 6.88 and the lowest value observed in well 1 as $12.42 \mathrm{mg} / \mathrm{L}$ with standard deviation of 1.33 during the wet season. Dissolved oxygen had the highest in well 3 as $10.22 \mathrm{mg} / \mathrm{L}$ in wet season. For bacteriological analysis, well 2 recorded the highest value of total coliform as $8.92 \mathrm{cfu} / 100 \mathrm{ml}$ during the wet season as against dry season of $1.46 \mathrm{cfu} / 100 \mathrm{ml}$. Highest value of total bacteria was also observed in well 1 during the wet season as $25.44 \mathrm{cfu} / 100 \mathrm{ml}$ with standard deviation of 1.64 and lowest in well 2 as $6.03 \mathrm{cfu} / 100 \mathrm{ml}$ with standard deviation of 0.38 . High concentration of the tested parameters during the wet season in well 3 was attributed to the nearnesss of sewage to the well and surface-groundwater interaction due to shallow nature of the well. Not all the samples meet the WHO and NSDWQ standard on drinking water quality most especially the bacteriological properties. It was recommended that wells most especially for community use should be deep enough and should be sited some distance away from any source of sewage and that water from wells should be treated before consumption.
\end{abstract}

Keywords: Sewage, Wells, Groundwater, Microbiological analysis

\section{Introduction}

Water is the second important resource to human life after air. Man can survive longer without food than without water. But in recent time, the quality of the water consumed has been a serious concern. Almost every aspect of man life requires adequate and timely supply of water to succeed. The pattern and level of life development depends to a great extent on the quality, quantity and rate of water supply to the species. Versari, et. al., (2002) put it that water is the essence of life and that safe drinking water is

*Corresponding Author: Adesiji, A.R.

Email: adrichard01@yahoo.co.uk a basic human right essential to all. Banu et. al., (2010) recorded that accessibility and availability of fresh, clean water is a key to sustainable development and essential element in health, food production and poverty reduction. According to Musa, et al., 2013, using shallow groundwater as sources for drinking and other domestic purposes is a common feature for many low income communities in developing countries. Solid wastes, mount of rubbish, garbage and sewage are being produced everyday in urban society. Globally about 1.3 billion metric tons of 
municipal solid waste was generated in 1990 (Beede and Bloom, 1995). At present, according to United State Environmental Protection Agency, USEPA, the yearly generation of solid waste equals to 1.6 billion metric tons approximately. In an attempt to dispose of these materials, man has carelessly polluted the environment. These pollutions have over the years contributed to degradation of the human environment which evidences could be seen in the various dumpsites and sewage drainage all over the community. Water pollution has continued to generate unpleasant implications for health and economic development in Nigeria (Adelegan, 2004). It is also important to note that a good and clean environment is very essential to good health. Timmer et al., 2005 as quoted by Samake et al. (2011), revealed that surface water has been exposed to varying degree of pollution primarily due to contamination associated with land use activities, including agricultural activities, leaking municipal sewage treatment facilities, poor septic management; uncontrolled cattle access to water bodies, sometimes becomes unavailable for drinking. Thus groundwater becomes the main drinking water resource in many parts of the world.

Groundwater which is used for domestic and industrial water supply and irrigation is vital to local people and industry in semi-arid and arid areas like Nigeria where it has become the main drinking water source. But it is rather unfortunate that this groundwater is so susceptible to contamination due to the indiscriminate ways by which wastes are disposed. According to Amadi ( 2009), contamination resulting from industry, urbanization and agriculture poses a threat to the groundwater quality. The improper disposal and treatment of this waste is one of the greatest environmental threats of the $21 \mathrm{st}$ Century. The impact of these wastes on soil and groundwater quality can be devastating, depending on the composition of the heterogeneous mixture and method of disposal, (Mohammed, 2011). Factors such as low capital cost required for the development of groundwater facilities, availability which is closeness to where water is needed and its natural quality (adequate for potable needs with little or no treatment) are influencing many developed and developing nations in changing to sub- surface source water supply for both domestic and industrial purposes.

Thousands of deaths every day mostly among the children under five years in developing countries has been attributed to the drinking of contaminated groundwater (WHO, 2004).

In the last few decades, there has been a tremendous increase in the demand for fresh water due to the rapid growth of population and the accelerated pace of industrialization. Human health is closely related with the groundwater quality and is threatened by the poor quality of groundwater caused by excessive application of fertilizers and unsanitary conditions. Rapid urbanization which caused groundwater pollution has affected the availability and quality of groundwater due to over exploitation and improper sewage disposal. Once groundwater is polluted, it is hard to stop the pollution and restore the water quality. It therefore becomes imperative to regularly monitor the quality of groundwater and to device ways and means of protecting it. Outbreak of diseases noticed among the children in recent time was attributed to the consumption of contaminated water and this is giving the relevant agencies concerns on the possible ways of ameliorating this trend. This study, therefore, focuses on investigating the effects of indiscriminate disposal of sewage on groundwater quality and the possible seasonal influence on the overall quality looking at two major seasons, dry and wet seasons.

\section{Materials and methods}

The study was carried out in Bosso Local Government area of Niger state - North Central Nigeria. The capital of Niger state is Minna with an average area of $76,363 \mathrm{~km}^{2}$ and estimated population of 350,287 in the 2006 (NPC). It is one of Nigeria's 36 states located between Latitude $9^{\circ} 15^{\prime \prime}$ and $9^{\circ} 45^{\prime \prime} \mathrm{N}$ and Longitude $6^{\circ} 15^{\prime \prime}$ and $6^{\circ} 45^{\prime \prime} \mathrm{E}$. Minna is connected to neighboring cities by road to Abuja and by rail/road to Kano in the north and Ibadan and Lagos in the south. Minna has an accelerated growth of commercial, farming and industrial activities on daily basis. As a result of the high population the area represents a zone of high domestic activities as well as commercial activities which leads to very high level of sewage and solid waste generation. 


\section{Collection of Samples}

Samples were collected from three different bore holes (deep wells), strategically chosen and all located within the study area. The depths of the wells considered ranged between 15 and $25 \mathrm{~m}$. In all these locations the water samples were collected on the day the tests were to be carried out in other to prevent any rise in temperature that may results from storing which may alter the properties of the water especially the bacteriological properties. The water samples were collected in newly bought plastic bottle which were sealed and have not been ever put in the mouth to prevent any contact with human waste. Each bottle was rinsed with the water it is to contain before the bottle was filled to two third of its volume. This is done in other to provide oxygen for the micro organism in the water so that they will not die before the test.

Soil samples were also collected in three replicates from each of the three wells at a depth of $90 \mathrm{~cm}$ which were used for sieve analysis and natural moisture content in the laboratory. This is necessary so as to determine the contributions of soil distribution patterns to the movement of the sewage to the groundwater body. The collected water samples were analyzed for microbiological qualities under parameters such as total coliform, faecal coliform, Escherichia coli and total bacteria count. The samples were also subjected to physico-chemical analyses to evaluate the following parameters; $\mathrm{pH}$, manganese high rate $\mathrm{mg} / \mathrm{l}$, Iron high rate $\mathrm{mg} / \mathrm{l}$, Calcium hardness $\mathrm{mg} / \mathrm{l}$, Phosphate low rate mg/l, Nitrate, Nitrite mg/l, Copper high rate $\mathrm{mg} / \mathrm{l}$, and Dissolved Oxygen $\mathrm{mg} / \mathrm{l}$ etc., as listed in the Table.

\section{Physico-Chemical Examination of Samples}

The samples, on collection were kept in insulated containers with ice packs and transported to the laboratory where they were to be tested for $\mathrm{pH}$, taste, odour. Turbidity, odour, sliminess and taste were determined by perception with the sense organs upon opening each sample while $\mathrm{pH}$ was determined by a combined glass electrode and a $\mathrm{pH}$ meter. Other physico-chemical parameters tested on the samples were; Manganese HR, Calcium hardness, Phosphate LR, Nitrate, Copper HR, and Dissolved Oxygen.

\section{Microbiological Examination of Samples}

In the microbiological analysis of the samples, an absorbent pad was placed into the empty sterilized dishes, $2 \mathrm{ml}$ of membrane lauryl sulphate broth (MLSB) was added. It was allowed to soak to saturate the pad and excess fluid was poured. Each water sample was filtered using 0.00045 and 45um 'membrane filtration techniques and after that the filtration paper was placed on the absorbent pad in the petri dish containing the media. The standard plate count is an agar method for estimating bacteria populations; it consists essentially of the following procedures: Total viable counts (aerobic mesophiles) were made on Plate Count Agar (PCA, Oxoid, U.K.). Coliforms were isolated using MacConkey broth and Eosin Methylene Blue agar. A $10^{\prime}$ dilution of each sample was enriched in tetrathionate broth (Difco) and incubated at $37^{\circ} \mathrm{C}$ for 6 hours before inoculation on Salmonella-Shigella agar (Oxoid) for isolation of salmonellae. Incubation was at $37^{\circ} \mathrm{C}$ for 24 hours. After incubation, all colonies from a sector of incubated plates were picked, purified by repeated sub-culturing before being examined microscopically for Gram reaction, cell morphology (using 24 hours old cultures), motility, pigmentation and sporulation.

\section{Soil Moisture Content Sieve Analysis}

The soil samples collected in-situ were taken to laboratory for soil moisture content test using oven-dry method and sieve analysis tests using Standard Test Method (ALPHA, 2005). The tests were carried out with the standard methods available and the results presented as shown in Tables 5 .

\section{Results \\ Physico-Chemical Examination}

The mean $\mathrm{pH}$ value of the samples ranged between 7.2 to 7.5 , with well 3 having the highest $\mathrm{pH}$ value compared with well 1 having the lowest with the average of 7.2 as presented in Table 1. The rest of the physico-chemical parameters' results carried out are as presented in Table 1. 
Table 1: Physico-Chemical analysis

\begin{tabular}{|c|c|c|c|c|c|c|}
\hline \multirow{2}{*}{ Parameter } & \multicolumn{2}{|l|}{ Well 1} & \multicolumn{2}{|l|}{ Well 2} & \multicolumn{2}{|l|}{ Well 3} \\
\hline & Dry Season & Wet Season & Dry Season & Wet Season & Dry Season & Wet Season \\
\hline $\mathrm{pH}$ meter & $7.5^{*} \pm 1.03$ & $6.9 \pm 0.37$ & $7.2 \pm 0.99$ & $6.8 \pm 0.56$ & $7.3 \pm 1.11$ & $6.5 \pm 0.11$ \\
\hline Phosphate LR (mg/l) & $2.2 \pm 0.65$ & $2.4 \pm 0.26$ & $3.7 \pm 0.58$ & $3.3 \pm 0.26$ & $2.3 \pm 0.43$ & $4.3 \pm 0.34$ \\
\hline Copper hr(mg/l) & $0.07 \pm 0.00$ & $0.12 \pm 0.03$ & $0.06 \pm 0.00$ & $0.38 \pm 0.04$ & $0.04 \pm 0.00$ & $0.62 \pm 0.09$ \\
\hline Nitrate $(\mathrm{mg} / \mathrm{l})$ & $0 \pm 0.00$ & $2.43 \pm 0.21$ & $0 \pm 0.00$ & $5.32 \pm 0.80$ & $18.3 \pm 0.27$ & $38.03 \pm 2.47$ \\
\hline Nitrite (mg/l) & $0 \pm 0.00$ & $0.04 \pm 0.00$ & $0.008 \pm 0.00$ & $0.00 \pm 0.00$ & $0.409 \pm 0.07$ & $0.96 \pm 0.05$ \\
\hline $\begin{array}{l}\text { Total dissolved } \\
\text { solid (mg/l) }\end{array}$ & $263.31 \pm 4.21$ & $161.44 \pm 7.21$ & $188.27 \pm 6.02$ & $98.54 \pm 2.97$ & $540.02 \pm 4.21$ & $233.09 \pm 2.67$ \\
\hline Chloride $(\mathrm{mg} / \mathrm{l})$ & $17.00 \pm 1.69$ & $12.42 \pm 1.33$ & $25.00 \pm 1.11$ & $45.98 \pm 3.14$ & $93.21 \pm 4.27$ & $143.93 \pm 6.88$ \\
\hline $\begin{array}{l}\text { Dissolved oxygen } \\
(\mathrm{mg} / \mathrm{l})\end{array}$ & $2.36 \pm 0.48$ & $6.71 \pm 0.49$ & $1.93 \pm 0.05$ & $4.90 \pm 0.37$ & $2.19 \pm 0.61$ & $10.22 \pm 2.04$ \\
\hline Turbidity (NTU) & $0.64 \pm 0.03$ & $3.24 \pm 0.92$ & $3.50 \pm 0.89$ & $7.43 \pm 0.47$ & $0.91 \pm 0.04$ & $3.21 \pm 1.09$ \\
\hline Conductivity $(\mu \mathrm{S} / \mathrm{cm})$ & $393.33 \pm 4.28$ & $189.43 \pm 6.27$ & $281.00 \pm 2.92$ & $224.91 \pm 7.33$ & $806.3 \pm 6.12$ & $764.36 \pm 5.88$ \\
\hline Odour & unobjectionable & Unobjectionable & unobjectionable & unobjectionable & unobjectionable & unobjectionable \\
\hline Taste & insipid & Insipid & insipid & Insipid & insipid & insipid \\
\hline Temperature $\left({ }^{\mathrm{O}} \mathrm{C}\right)$ & $25.9 \pm 1.03$ & $24.2 \pm 2.01$ & $25.9 \pm 0.93$ & $24.90 \pm 1.35$ & $25.8 \pm 1.92$ & $25.12 \pm 2.00$ \\
\hline
\end{tabular}

*Values are means of triplicate readings \pm standard error 
Table 2: Comparing the means of Physico-chemical Parameters Using New Duncan Multiple Range Tests

\begin{tabular}{lccccccccccc}
\hline Treatment & $\mathrm{pH}$ & $\mathrm{Temp}$ & $\mathrm{PO}_{4}^{-3}$ & $\mathrm{Cu}$ & $\mathrm{NO}_{3}^{-}$ & $\mathrm{NO}_{2}^{-}$ & $\mathrm{TDS}$ & $\mathrm{Cl}$ & $\mathrm{DO}$ & Turb. & EC \\
\hline Dry & $7.33^{\mathrm{a}}$ & $25.8^{\mathrm{a}}$ & $2.73^{\mathrm{a}}$ & $0.06^{\mathrm{a}}$ & $6.1^{\mathrm{a}}$ & $0.14^{\mathrm{a}}$ & $330.53^{\mathrm{a}}$ & $45.07^{\mathrm{a}}$ & $2.16^{\mathrm{a}}$ & $1.68^{\mathrm{a}}$ & $493.54^{\mathrm{a}}$ \\
Wet & $6.73^{\mathrm{a}}$ & $24.7^{\mathrm{a}}$ & $3.33^{\mathrm{a}}$ & $0.37^{\mathrm{b}}$ & $20.43^{\mathrm{b}}$ & $0.33^{\mathrm{a}}$ & $164.36^{\mathrm{b}}$ & $67.37^{\mathrm{b}}$ & $7.27^{\mathrm{b}}$ & $4.63^{\mathrm{b}}$ & $159.57^{\mathrm{b}}$ \\
\hline
\end{tabular}

Mean data on the same column accompanied by different superscripts are significantly different while mean data on the same column with same superscript are not significantly different. (New Duncan's Multiple Range Test, $p<0.05)$. EC-Electrical Conductivity, TSS- Total Dissolved Solids, DODissolved Oxygen.

\section{Microbiological Examination}

For each sample to be examined, an absorbent was placed into empty sterile petri dishes, $2 \mathrm{ml}$ of membrane lauryl sulphate broth (MLSB) was added sufficiently to saturate the pad in different dispense petri dishes and allowed to soak in and any excess fluid was pour away. The standard plate count is an agar method for estimating bacteria populations; it consists essentially of the following procedures: Total viable counts (aerobic mesophiles) were made on Plate Count Agar (PCA, Oxoid, U.K.). Coliforms were isolated using MacConkey broth and Eosin Methylene Blue agar. A 10 dilution of each sample was enriched in tetrathionate broth (Difco), incubated at $37^{\circ} \mathrm{C}$ for 6 hours before inoculation on Salmonella-Shigella agar (Oxoid) for isolation of salmonellae. Incubation was at $37^{\circ} \mathrm{C}$ for 24 hours. After incubation, all colonies from a sector of incubated plates were picked, purified by repeated sub-culturing before being examined microscopically for Gram reaction, cell morphology (using 24 hours old cultures), motility, pigmentation and sporulation. The summary of the result is as presented in Table 2.

Table 3: Microbiological analysis

\begin{tabular}{|c|c|c|c|c|c|c|}
\hline \multirow{2}{*}{ Parameter } & \multicolumn{2}{|l|}{ Well 1} & \multicolumn{2}{|l|}{ Well 2} & \multicolumn{2}{|l|}{ Well 3} \\
\hline & Dry Season & Wet Season & $\begin{array}{l}\text { Dry } \\
\text { Season }\end{array}$ & Wet Season & Dry Season & Wet Season \\
\hline $\begin{array}{l}\text { Total Coliform } \\
\text { (cfu/100ml) }\end{array}$ & $0.00 * \pm 0.00$ & $3.69 \pm 0.22$ & $1.46 \pm 0.29$ & $8.92 \pm 0.47$ & $0.00 \pm 0.00$ & $0.00 \pm 0.00$ \\
\hline $\begin{array}{l}\text { Faecal Coliform } \\
\text { cfu/100ml) }\end{array}$ & $0.00 \pm 0.00$ & $2.01 \pm 0.04$ & $0.00 \pm 0.00$ & $0.00 \pm 0.00$ & $0.00 \pm 0.00$ & $1.09 \pm 0.01$ \\
\hline $\begin{array}{l}\text { Total Bacteria } \\
\text { count cfu/100ml) }\end{array}$ & $14.23 \pm 0.68$ & $28.99 \pm 1.64$ & $6.03 \pm 0.38$ & $16.03 \pm 1.02$ & $15.86 \pm 0.27$ & $25.44 \pm 1.04$ \\
\hline $\begin{array}{l}\text { Salmonella } \\
\text { shigella } \\
\text { cfu/100ml) }\end{array}$ & $0.00 \pm 0.00$ & $0.00 \pm 0.00$ & $0.00 \pm 0.00$ & $0.00 \pm 0.00$ & $0.00 \pm 0.00$ & $0.00 \pm 0.00$ \\
\hline
\end{tabular}

Table 4: Comparing the means of Bacteriological Parameters Using New Duncan Multiple Range Tests

\begin{tabular}{lllll}
\hline Treatment & Total Coliform & $\begin{array}{l}\text { Faecal } \\
\text { Coliform }\end{array}$ & $\begin{array}{l}\text { Total Bacteria } \\
\text { Count }\end{array}$ & $\begin{array}{l}\text { Salmonella } \\
\text { Shigella }\end{array}$ \\
\hline Dry & $0.48^{\mathrm{a}}$ & $0.00^{\mathrm{a}}$ & $12.04^{\mathrm{a}}$ & 0.00 \\
Wet & $4.20^{\mathrm{b}}$ & $1.03^{\mathrm{b}}$ & $20.15^{\mathrm{b}}$ & 0.00 \\
\hline
\end{tabular}

Mean data on the same column accompanied by different superscripts are significantly different while mean data on the same column with same superscript are not significantly different. (New Duncan's Multiple Range Test, $p<0.05)$. 
Table 5: Average Natural Moisture Content of the samples around the three wells

\begin{tabular}{llll}
\hline Tests & Well 1 & Well 2 & Well 3 \\
1 & 15.42 & 16.80 & 16.23 \\
\cline { 2 - 4 } 3 & 15.68 & 16.43 & 16.50 \\
3 & 15.93 & 16.92 & 16.13 \\
Average \% & 15.68 & 16.72 & 16.29 \\
\hline
\end{tabular}

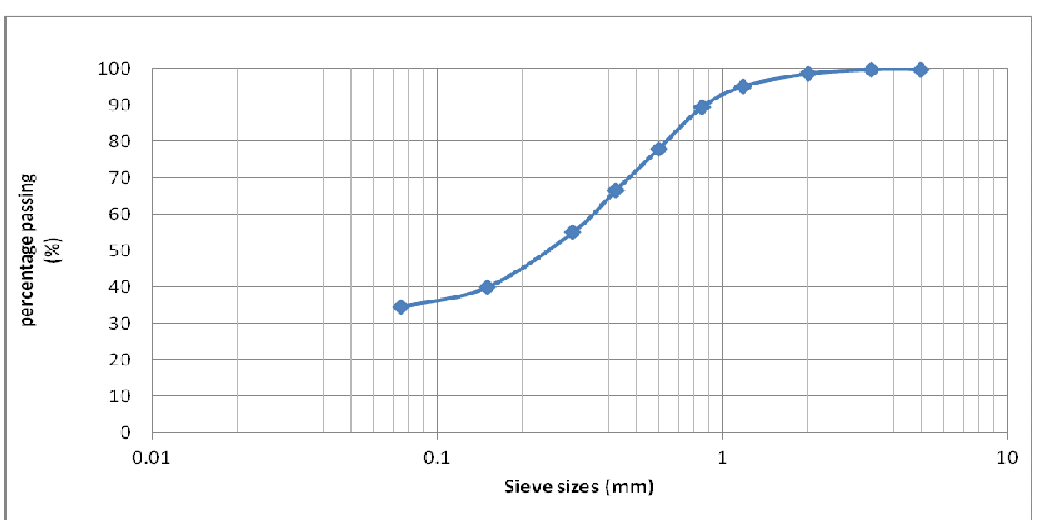

Figure 1: Sieve analysis curve for soil around well 1

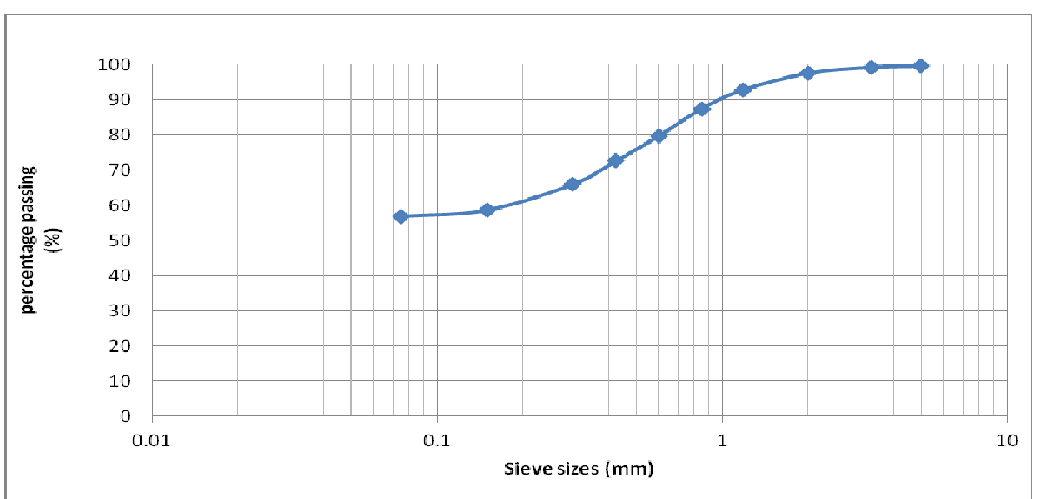

Figure 2: Sieve analysis curve for soil around well 2

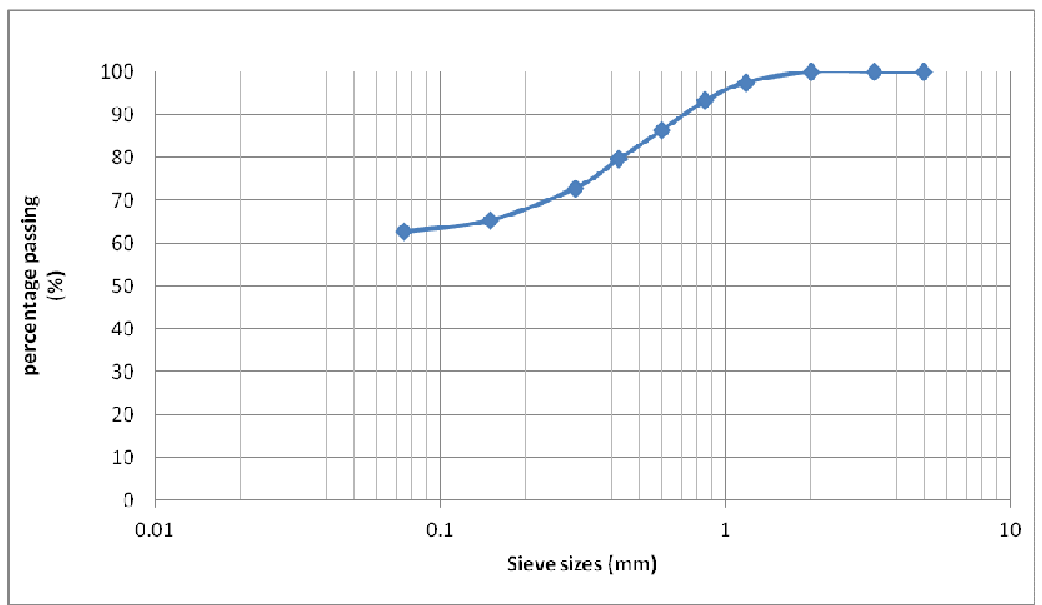

Figure 3: Sieve analysis curve for soil around well 3

\section{Moisture Content and Particle Size Distribution of Soil}

The results of the natural moisture content conducted on the soils around the three wells show that soil around well 3 has the highest water holding capacity, followed by that of well 2 and well 1 with the lowest water holding capacity. Hence soil mass around well 1 is more permeable when compared to the other two wells. According to the Australian standards 
AS1726-1993 and Unified Soil Classification System, the geotechnical characteristics of a soil are significantly influenced by percentage of fine present. Therefore, the following can be deduced from the graph:

i. $\quad$ Percentage fine in well $1=34.47 \%$ (well graded coarse grained soil)

ii. Percentage fine in well $2=56.81 \%$ (well graded fine grained soil)

iii. Percentage fine in well $3=62.53 \%$ (well graded fine grained soil)

From the above result the soil around well 1 is more pervious and will have more interconnected pore spaces followed by that of wells 2 and 3 .

\section{Discussion \\ Physico-Chemical examination}

From the physico-chemical examination carried out on the samples as shown in Table 1, for copper HR the observed value ranged from $0.04 \mathrm{mg} / \mathrm{l}$ in well 2 during the dry season with the standard deviation (SD) of zero and 0.62 $\mathrm{mg} / \mathrm{L}$ in well 3 during the wet season with SD of 0.09 . The nitrate value ranged from 2.43 $\mathrm{mg} / \mathrm{L}$ in well 1 during the wet season with SD of 0.21 to $38.03 \mathrm{mg} / \mathrm{L}$ during the wet season in well 3 ( $\mathrm{SD}=2.47)$, with no value recorded in well 1 during the dry season as a result of no samples. Total dissolved solid (TDS) was recorded and ranged from $98.54 \mathrm{mg} / \mathrm{L}$ in well 2 during the wet season with SD of 2.97 to $540.02 \mathrm{mg} / \mathrm{L}$ in well 3 during the dry season with SD of 4.21. Chloride in the samples was observed lowest in well 1 during the wet season as $12.42 \mathrm{mg} / \mathrm{L}$ with $\mathrm{SD}$ of 1.33 and highest in well 3 during the wet season as $143.93 \mathrm{mg} / \mathrm{L}$ with SD of 6.88. the values of dissolved oxygen, DO, ranged from $1.93 \mathrm{mg} / \mathrm{L}$ in well 2 during the dry season with SD of 0.05 to 10.22 $\mathrm{mg} / \mathrm{L}$ in well 3 during the wet season $(\mathrm{SD}=$ 2.04). Electrical conductivity of the samples recorded the lowest value in well 1 during the wet season as $189.43 \mu \mathrm{s} / \mathrm{cm}$ with SD of 6.27 and highest in well 3 during the dry season with $\mathrm{SD}$ of 6.12 . temperature ranged from $24.20^{\circ} \mathrm{C}$ in well 1 during the wet season with SD of 2.01 to $25.90^{\circ} \mathrm{C}$ in both wells 1 and 2 during the dry season with SD of 1.03 and 0.93 respectively. Odour and turbidity did not pose any risk as the samples in the three wells satisfied these requirements. For copper HR, all the three wells gave the values that lie below the maximum permissible limit of $1.0 \mathrm{mg} / \mathrm{l}$ specified by the NSDWQ and $2.0 \mathrm{mg} / \mathrm{l}$ specified by the WHO. For Nitrate $\left(\mathrm{NO}_{3}\right)$, wells $1 \& 2$ give Nitrate value as zero which is ok and within the limit specified by the NSDWQ. For well 3 the Nitrate value is $18.3 \mathrm{mg} / \mathrm{l}$ during the dry season, which is above the limit specified by the NSDWQ but still within the limit $50 \mathrm{mg} / \mathrm{l}$ specified by the WHO standard. Total dissolved Solids, TDS for wells $1 \& 2$ lie below the maximum permissible limit of $500 \mathrm{mg} / \mathrm{l}$ as specified by the NSDWQ while well 3 has TDS above $500 \mathrm{mg} / \mathrm{l}$. However, the entire three samples meet the maximum permissible limit of the WHO. The three wells gave the value of chloride which is far below $100 \mathrm{mg} / \mathrm{l}$ maximum permissible by the NSDWQ except well 3 with the highest value of $143.93 \mathrm{mg} / \mathrm{l}$ during the wet season. The three wells also gave the values of Dissolved Oxygen, DO which lie below $5 \mathrm{mg} / \mathrm{l}$ maximum permissible limit by the WHO except wells 1 and 3 during the wet season for obvious reasons. The other remaining parameters such as odour, turbidity and conductivity are all satisfied as the values recorded fall below the maximum permitted by the two standards, WHO and NSDWQ.

\section{Microbiological Examination}

For Total coliform count, no coliform was found in well 3 during the two seasons, but well 2 recorded the highest total coliform of 8.92 $\mathrm{cfu} / 100 \mathrm{ml}$ during the wet season with SD of 0.47 and well 1 , the lowest value of 3.69 $\mathrm{cfu} / 100 \mathrm{ml}(\mathrm{SD}=0.22)$ during the wet season and none during the dry season. This according to the NSDWQ standard is traceable to recent contact with the environment, which is as a result of seepage of sewage through the soil mass into the groundwater below. Among all the sampled wells, no faecal coliform was detected in well 2 in both seasons except during the wet seasons for both wells 1 and 3, showing that the water is safe and in compliance with the NSDWQ standard for drinking water in dry seasons when there is no more runoff aiding the movement of sewage into the groundwater. However, for Total Bacteria count (E.coli), well 1 has a total of $14.23 \mathrm{cfu} / 100 \mathrm{ml}$ during the dry season $(\mathrm{SD}=0.68), 28.99 \mathrm{cfu} / 100 \mathrm{ml}$ in wet season and well 2 has $6.03 \mathrm{cfu} / 100 \mathrm{ml}$ in dry season and $16.03 \mathrm{cfu} / 100 \mathrm{ml}$ in wet season. Well 3 has $15.86 \mathrm{cfu} / 100 \mathrm{ml}$ during the dry season and $25.44 \mathrm{cfu} / 100 \mathrm{ml}(\mathrm{SD}=1.04)$ in wet season. According to the NSDWQ standard a maximum of 10 counts is permissible, from 
above only well 2 satisfied the requirement during the dry season as far as Total bacterial count is concerned. Total bacteria count does not cause illness. However, their presence in public water system is a health concern because of the potential for disease causing strains of bacteria, viruses and protozoa to also be present. No salmonella shigella was found in all the three wells in both seasons considered. This also is in accordance with the standards.

\section{Conclusion}

The water from these wells require further treatment before drinking as most of them do not satisfy the requirements of NSDWQ and WHO in the area of physic-chemical analysis and microbiological analyses. In the area of microbiological analysis the three wells exhibited varying degree of characteristics. All the Wells, during the dry season, have no traces of faecal coliform which shows that the water is safe for drinking and it is in compliance with the NSDWQ standard for drinking water during this season, but with traces of faecal coliform during the wet season due to increased runoff discharge which helps in transporting the sewage particles to the groundwater. However, for Total Bacteria count (E.coli), only well 2 during the dry season satisfies the requirement though the presence of total bacteria count does not cause illness. However, their presence in public water system is a health concern because of the potential for disease causing strains of bacteria, viruses and protozoa to also be present. Waterborne diseases from these organisms typically involve flu-like symptoms such as nausea, vomiting, fever and diarrhea. Values of TDS and conductivity during the dry season are higher than those of wet season. The scenario which may be attributed to dilution due to more recharge during the wet season. This was supported by Pritchard et al., (2008) and Nkandawire, (2008) findings. More contamination during the wets season may be attributed to surface-groundwater interaction due to shallow nature of the well, high hydraulic conductivity of the soil due to its sandy nature or possibly as a result of low attenuation capacity of the soil in the area (Lerner and Harris, 2009).

\section{References}

Adelegan, J.A. (2004). The History of Environmental Policy and Pollution of
Water Sources in Nigeria (1960-2004): The way forward. Available at http://web.fuberlin.de/ffu/akumwelt/bc2004 /download/adelegan_f.pdf. Accessed 24th Mar, 2011.

APHA, AWWA, and WEF, (2005). Standard Methods for the Examination of Water and Wastewater, $21^{\text {st }}$ ed. American Public Health Association, Washington, D.C.

Amadi, A.N. (2009). Physio-chemical and Bacteriological Evaluation of Groundwater in parts of Aba, Abia State, Southeastern Nigeria. International Journal of Applied Biological Research, 1(1): pp 63-71.

Banu, N. and Menakuru, H. (2010). Enumeration of microbial contaminants in sachet water: a public health challenge. 2(6), 582-588.

Beede, D. N. and Bloom, D.E. (1995). The economics of municipal solid waste. World Bank Research Observer, 10(2): 113-150.

Lerner, D.N. and Harris, B. (2009). The relationship between land use and groundwater resources and quality. Land Use Policy 26s: S265 - S273.

Musa, J. J. and Ahanonu, J. J. (2013). Quality Assessment of Shallow Groundwater in Some Selected Agrarian Communities in Patigi Local Government Area, Nigeria. International Journal of Basic and Applied Science, 1(3): 548-563.

Nkandawire, T. (2008). Quality of groundwater from shallow wells of selected villages in Blantyre district, Malawi. Physics and Chemistry of the Earth, 33: 807 - 811.

Pritchard, M., Nkandawire, T. and O'Neill, J.G. (2008). Assessment of groundwater quality in shallow wells within the southern districts of Malawi. Physics and Chemistry of the Earth, 33: 812 - 823.

WHO/UNICEF (2004). Meeting the MDG Drinking Water and Sanitation: A MidTerm Assessment of Progress. Geneva: WHO/UNICEF. ISBN 9241562781.

Samake, M., Hlaing, Z. T. and Ndoh Mbue, I. (2011). Groundwater Vulnerability Assessment in Shallow Aquifer in Linfen Basin, Shanxi Province, China Using DRASTIC Model. Journal of Sustainable Development, 4(1): 53-71.

Versari, A., Parpinello, G. P., and Galassi, S. (2002). Chemometric survey of Italian bottled mineral waters by means of their labeled pysico-chemical and chemical composition. J. Food Compos Anal, 12: 251264. 